\title{
The challenges of applying refitting analysis in the Palaeolithic archaeology of the twenty-first century: an actualised overview and future perspectives
}

\author{
Francesca Romagnoli ${ }^{1} \cdot$ Manuel Vaquero ${ }^{2,3}$ \\ Published online: 27 June 2019 \\ (C) Springer-Verlag GmbH Germany, part of Springer Nature 2019
}

\begin{abstract}
Refitting of lithic artefacts is a unique method. When two pieces go CLICK-this is it! There is no other match possible. In archaeology this is probably our best example of "scientific proof", but, in the end, the interpretation of the CLICK depends on the fundamental questions asked by the researcher and the overall methodology applied. Eriksen 2009:141
\end{abstract}

\section{Introduction}

The refitting of lithic artefacts has a long tradition in Palaeolithic archaeology, having been used in stone tool studies since the 1880s (Smith 1894; Spurrell 1880). Until the late 1960s, this method, which consists of finding the joints between stone elements extracted from the same block, much like a 3D jigsaw puzzle, was only discontinuously and occasionally applied. Since then, the increasing use of refits has most likely been caused by the quality of the archaeological record found at the Magdalenian site at Pincevent in France,

Francesca Romagnoli

francesca.romagnoli@uam.es

$\triangle$ Manuel Vaquero

manuel.vaquero@urv.cat

1 Departamento de Prehistoria y Arqueología, Universidad Autónoma de Madrid (UAM), Ciudad Universitaria de Cantoblanco, 28049 Madrid, Spain

2 Institut Català de Paleoecologia Humana i Evolució Social (IPHES), Zona Educacional 4, Campus Sescelades URV (Edifici W3), 43007 Tarragona, Spain

3 Àrea de Prehistoria, Universitat Rovira i Virgili (URV), Avinguda de Catalunya 35, 43002 Tarragona, Spain where the reconstruction of the social and economic organisation of reindeer hunter communities was allowed through refits (Leroi-Gourhan and Brézillon 1966, 1972). During these early years, refitting analysis was not only introduced to European studies, for example at Gönnersdorf in Germany (Bosinski 1975), but also in Africa at Munyama Cave by Victoria Lake (van Noten 1971) and Gombe in Zaire (Cahen 1976) and in North America at the Casper site in Colorado (Frison 1974). Since the 1970s, refits have been applied mainly to two fields of research: taphonomy and 'anthropological' studies (Larson and Ingbar 1992:151). In taphonomic studies, refits have been used to evaluate the non-anthropic and postdepositional processes that have caused the displacement of archaeological items (e.g. Hofman 1986; Villa 1982). The anthropological application of refits has been mainly focused on two research lines: technology and intra-site spatial distribution (for a complete bibliography on the history of refitting, see Arts and Cziesla 1990 and Schurmans 2007). Looking at the technological studies, refits have been used to reconstruct stone tool production processes and transport. Some multidisciplinary studies have included use-wear analysis to investigate the relationship between a specific stone tool and its function (Cahen et al. 1979; Odell 1981). For spatial applications, refits have been used to investigate settlement dynamics through the identification of intra-site activity areas (characterised by the clustering of archaeological remains and a high rate of refits) and the relationships between these areas as highlighted by intra-site connection lines between long-distance refitted items. Based on the extension of an activity area and the technological characteristics of the refitted items, refits have also been applied sporadically for identifying the number of occupational events in an activity area and inferring the number of individuals knapping there (Cahen and Keeley 1980).

In 1987, refits were formally acknowledged for the first time as a preferred method for reconstructing and understanding the past. In that year, Erwin Cziesla, Sabine Eickhoff, Nico 
Arts, and Doris Winter organised "The Big Puzzle" international symposium at Monrepos in Neuwied, Germany. It was a milestone in the standardisation and implementation of refitting studies in Palaeolithic contexts. The participants at the symposium made a significant improvement to the methods of refitting analysis through theoretical reflections and the development of a standardised terminology, for example for production-sequences, broken artefacts, and modifications involving retouched tools (Cziesla 1990:15), and protocol for representing connection lines between refitted elements and their intra-site spatial distribution (Cziesla et al. 1990). In addition to the theoretical and methodological systematisation of refitting analysis, we believe that the main achievement of the symposium and its most relevant contribution to latter studies was in its highlighting of the great informative value of refits when analysed from a holistic and multidisciplinary perspective. The data published since then have shown that refitting is productive for reconstructing site formation and taphonomic processes (McCall 2010; Morrow 1996) and have enlarged its application to include bone assemblages (Hofman and Enloe 1992). Furthermore, refitting analysis has significantly improved behavioural archaeology (Schiffer 1976; Smith et al. 2012) and the knowledge of how ancient hominins moved into the landscape, built economic strategies, and organised their social spaces at campsites (McCall 2014; Schurmans and De Bie 2007). Refits have also allowed for a deeper look into the status and skill of stone knappers even from Palaeolithic times (Bodu et al. 1990), an ancient period for which these topics would otherwise be unlikely to understand.

To celebrate the 30th anniversary of The Big Puzzle, we organised an international workshop in Tarragona, Spain, through a grant from the Wenner-Gren Foundation (Romagnoli and Vaquero 2018). Since many years have passed since the Monrepos symposium, we believed that is was time to evaluate whether the expectations raised 30 years ago had since been met. The 3-day workshop was a stimulating opportunity to sum up the reality of refitting analysis in recent years and to debate the challenges that this method will face in the new millennium. The workshop involved a novel format that included the collective analysis of archaeological and experimental materials during work sessions, allowing for a debate of in-depth questions on terminology and technology. Both lithic and bone materials were shown and analysed. In this paper, we briefly present the main topics that received new motivation through the application of refitting analysis and introduce the papers collected in this volume, which represent the latest, multidisciplinary applications of refits in current Palaeolithic archaeology. Some of the remarks that arose from the thoughts and discussions at the workshop are also presented, and they are all strictly related to how archaeological science is changing in the new millennium.

\section{Refits: still a privileged method for understanding and interpreting past human behaviours}

In recent decades, several topics in human evolution studies have received revitalization through the use of refitting, while the application of this technique is still not systematic in Palaeolithic research. We will discuss more about the reasons behind this limitation later in the paper. The renewed focus in the current debate of Palaeolithic studies on the diversity of past human behaviours has been partially caused by the application of refitting analysis. This method has opened up new perspectives on the perception of the spatial organisation of human activities and their temporal relations (Turq et al. 2013; Vaquero 2008, 2011). This last topic in particular has encouraged a novel reflection on the temporal resolution of archaeological contexts (for discussion, see Romagnoli et al. 2018a). Refitting offers a glimpse at the temporal scale that defines the basic units forming archaeological assemblages: the scale of each event. Focusing on lithics, refitted elements are the direct evidence of in situ knapping events. An analysis of refits enables researchers to discern between different events and investigate the temporal relations between them. For example, it is possible to identify the life history of a tool from the finding of its raw material to its abandonment as a used item. If humans introduced a raw material into a site as an entire block and knapped it there, we can find refitted sequences, including the cortical blanks that were produced during the first phases of knapping. In addition to production events, selection and transportation events can be also identified through refits, both at the intra- and inter-site level. The study of the intra-site spatial distribution of refitted elements and the distance and direction of refitting lines combined with a taphonomic analysis of postdepositional agents allows for the identification of the anthropic redistribution of produced tools between different domestic units at a site. Finally, through refits, we are able to identify 'ghosts' and 'orphans' as evidence of processes that are extremely difficult to perceive in archaeology, such as lacking items that were there previously but were later taken away by humans. If refitted blocks can rebuild almost a complete initial volume but some items are systematically lacking (and especially if the technological analysis identifies them as 'primary' products strictly related with the knapping method being applied), we are seeing 'export events'. This means that the missing items were part of a toolkit that was produced at the site and then exported to be used elsewhere as an element of the planned economic strategies of hunter-gatherers during their annual displacements. At the same time, if some items are lacking for refitting, and especially if it is 
possible to corroborate the character of the isolated items through the specificity of their morpho-technical and petrographic characteristics, we may have a transported toolkit that was produced elsewhere and introduced into the site ready to be used by the hunter-gatherers.

Ultimately, refits permit researchers to deal with time in archaeological contexts in two ways: they allow the study of static archaeological objects as part of a dynamic, and they allow dealing with the cumbersome problem of identifying of contemporaneity and diachrony between archaeological events. This was one of the main topics discussed at the workshop as it places the interpretation of refitting patterns at the centre. Although connections between activity areas have often been considered as indicating that the areas were contemporaneous, the potential practice of recycling forces us to be particularly cautious about this point, especially concerning lithic refits. It has been suggested that bone refits are more suitable for indicating that two areas were contemporaneous (O'Brien 2015; Rapson and Todd 1992) due to the restricted time span during which a bone is still useful. Nevertheless, the entirety of a refitting pattern may provide some clues on this issue, in particular on the directionality of the movementsunidirectional or bidirectional. Bidirectional patterns would be more consistent with a hypothesis that the connected areas were contemporaneous, while a recycling hypothesis cannot be discarded for unidirectional patterns. At the same time, the informative value of refits lies in the application of this method along with other approaches. Embedding stone tool refits in a multidisciplinary research programme, including petrographic, morpho-technical, and use-wear analyses, and geostatistical and spatial modelling, gives consistency to a working hypothesis, reinforces scientific demonstration, and opens different perspectives for understanding the social behaviours of past communities. Over the last two decades, the value of refits in archaeological science and the increase in their application in multidisciplinary studies have given new energy to several topics in Palaeolithic studies. These can be classified into three domains: site formation processes, technical behaviours, and social behaviours in domestic spaces.

Site formation processes Archaeological layers are palimpsests. They result from several diachronic and independent import, production, use, export, and discard events (Bailey 2007). Refitting has been shown to be a privileged method for dissecting archaeological palimpsests. It provides for a reduction of the temporal scale of analysis. An archaeological layer is usually approached as a single whole, while refits enable the identification of different events that make up the archaeological collection of each layer and the assessment of the temporal relationships between them. From this perspective, refits provide useful information about post-depositional processes and dynamics and the definition of stratigraphic integrity (e.g. Deschamps and Zilhão 2018; Sisk and Shea
2008), and they also enable the identification of knapping areas, refuse deposits, and storage spaces (e.g. Delagnes et al. 2006a; López-Ortega et al. 2017). Refits enable the introduction of time as a variable in archaeological analysis. This implies that analyses of the intra-site spatial distribution of refitted items, the direction and movement of their connection lines, the number of technical events in each area, and the archaeological categories associated with the items make it possible to identify recycling and discuss the capacity for planning of past communities. For example, the intentional displacement of artefacts within a site demonstrates the economic strategies of the human group. Furthermore, we can infer the duration of human occupation at a site and discuss settlement patterns (Gaudzinski-Windheuser et al. 2011; Machado et al. 2017). Obviously, this study domain is strictly related to an analysis of site function and economic strategies such as curation and expediency (Vaquero and Romagnoli 2018; Vaquero et al. 2015) and the more general and complex topic of mobility in archaeology (Close 2000; Baena Preysler et al. 2018).

Gaining an understanding of assemblage and site formation processes can also be approached using bone refits (Audouze and Enloe 1997). Faunal remains have been included in refitting programmes less often than stone tools; however, they are diagnostic elements useful for discussing synchronicity and diachrony between carcass transport and processing events (Rosell et al. 2012). Bone refits contribute to dissecting archaeological palimpsests and understanding taphonomic dynamics, especially when applied along with archaeostratigraphy, zooarchaeological study (Morin et al. 2005), and tooth wear analysis (Gabucio et al. 2018). They reinforce the contributions of settlement patterns especially when they are associated with lithic refits (Bargalló et al. 2016) as lithics and bones can be characterised by different intra-site mobility patterns created between activity areas and can have different economic values in relation to recycling and refuse disposal (Vaquero et al. 2017). Furthermore, the identification of single events through bone refits has increased the knowledge of Neanderthal foraging strategies on a short scale, showing the link between the consumption of large mammals and other resources (Gabucio et al. 2014).

Technical behaviours Refits are very useful for showing the variability of technical systems. In fact, the majority of studies in which refits have been applied are devoted to interpreting past technical behaviours, including knapping concepts and methods and strategies for tool transport (what circulates in the pockets of past humans, how and why, as stated in the title of a paper by our French colleagues, Delagnes et al. 2006b). Furthermore, in recent years, a small number of papers have been published that use refits to discussing the flexibility of knapping methods. These studies have indicated that the human decisions made during knapping processes were not 
rigidly determined by unchangeable mental templates, but rather, the search for a specific tool morphology or functional edge led to the interlocking of different technical options to adapt to raw material constraints, respond to different risks, or meet to a lack of specific skills. Moreover, identifying the knapper's choices and decisions may help permit researchers to discern some of the idiosyncratic signatures characterising specific individuals (Foulds 2010).

Even if there have been few case studies that have applied refits to investigate these topics, these studies have clearly shown the potential for this method within a multidisciplinary research design in creating a better understanding of human responses to specific constraints and determining technological behaviours in relationship to the environment, technological costs and knowledge, and social organisation. We will now provide some recent applications as examples. A recent study has highlighted how Neanderthals adapted their initial production phases to the removal of the most inhomogeneous part of a block. In addition, they further exploited the parts of the block of the highest quality, creating a specific variant of the Levallois production sequence to overcome the costs of raw material quality and to exploit a single resource for knapping methods with a high and low degree of control on final products (Romagnoli et al. 2016). Moreover, stone tool refits allow for the identification of which blanks a knapping procedure is mainly designed for and the recognition of the variability in the technical procedures that were applied to achieve these technological goals (Bachellerie et al. 2007; Bernard-Guelle et al. 2017; Ortiz Nieto-Márquez and Baena Preysler 2017). Recent studies have shown a great variability in the economic behaviours hidden in the concept of ramification in the Middle Palaeolithic, and these behaviours respond to the different strategies that led the choices regarding which tools will circulate as personal gear and why (Romagnoli et al. 2018b; Turq et al. 2013). In addition, the intra-site movement of lithics indicates which types of artefacts were more likely to have been considered as useful, allowing for the concept of the tool in Palaeolithic technologies to be assessed (Clark 2019). Looking at specific individual constraints, refits have permitted the identification of human laterality in Middle Palaeolithic contexts (Bargalló et al. 2017) and the detection of apprentices (see Castañeda 2018:719 and the bibliography therein). Therefore, refitting analysis integrated into technological studies provides a detailed understanding of adaptive behaviours. This knowledge is needed to interpret the relationships between humans and the landscape, their shared knowledge, and its mechanism of transmission.

Domestic social behaviours Since the first applications of refitting studies, the spatial distribution of refits has been used to visualise and interpret the use of living spaces and to understand settlement patterns. These goals have been achieved through the study of bone refits, lithic refits, and the association between both of these categories of archaeological remains. The reconstruction of social spaces necessarily must be done from a multidisciplinary perspective, taking into account the density of the remains, their spatial clustering and segregation, the taphonomy and archaeostratigraphy, and the technological and subsistence strategies of human groups. Determining intra-site settlement patterns is needed to link models of mobility with lifeways and socio-economic behaviours. The relationships between these aspects are dynamic and must thus be explained from a dynamic perspective, and accordingly, refits breathe life into static archaeological contexts. Furthermore, the perception of short-scale events enables the specification of varied phenomena and the taking into account of social dynamics and isolated behaviours that were not related in time. It is therefore possible to identify and interpret activity areas, including sleeping areas, production zones, and spaces for carcass processing. According to the spatial and temporal analyses of ethnographic camps (Binford 1978a, b), the managing of living spaces and the organisation of tasks in the different areas of a campsite are related to behavioural complexities and are well established in Upper Palaeolithic sites (see Brenet et al. 2018; GaudzinskiWindheuser 2015; Jöris et al. 2011; Julien and Karlin 2014; Street et al. 2006; within the more recent papers for this chronology). The organisation of daily activities and the degree of complexity involved in their planning and management are key topics in Neanderthal studies as they are strictly related to their social and cognitive features. Refits have significantly improved our understanding of Neanderthal lifeways through the identification of hearth-related activity areas, the organisation within domestic units, the presence of communal spaces, and waste management strategies at campsites. They have also allowed for a consideration of the duration of the occupation of a site (e.g. Chacón et al. 2015; Modolo and Rosell 2017).

The main benefit of applying refits to intra-site spatial analysis is the possibility of dealing with the temporal relationships between domestic units. By looking at the distribution and direction of the connection lines between refitted items, it is possible to reconstruct the anthropic displacement of artefacts between different areas. For example, if we identify a knapping area, which we call 'area A', it must be characterised by the presence of a refit composed of cortical flakes (related to the first phase of production) and the occurrence of debris, fragments, and flakes of variable dimensions made of a lithic resource with the same macroscopic characteristics as the refitted elements. Alternatively, area A needs the presence of several flakes, at least partially refitted, related to a single block of raw material. Let us call this refitted set 'R-01'. This set must be composed of at least four items, and three of them must be clustered in area A (plus the other elements attributable to the same block based on their macroscopic characteristics and petrography). We may also find that one 
piece of R-01 is spatially isolated in a different area within the site located several meters away, which we call 'area B'. Once we laminate natural processes through taphonomic analysis (for example the circulation of water), we can link the presence of this piece in area B to human activity. An individual took a flake from area $\mathrm{A}$ and transported it to be used or discarded in area B (it may or may not have been by the same individual who knapped the block, we cannot know). If R-01 is composed of two items, and one is stored in area $\mathrm{A}$ while the other is in area B, we cannot know whether the movement was from area $A$ to area $B$ or vice versa, although we still have an evidence of a link between the two different activity areas caused by human activity and space management. Likewise, we can link different areas according to the long-distance bone refits related to the same anatomical portion of an animal. In this case, it may be more difficult to draw a direction line due to the usually low number of refits per set in bone assemblages.

The intra-site movement of lithics may be due to the social and economic interactions between individuals in a campsite or to the later exploitation of artefacts and resources left at the site previously (strategies of storage, scavenging, or recycling, Vaquero et al. 2015, 2017). In particular, bone refits can provide information about the technological processes in preycarcass treatment, including butchery and consumption, and their intra-site spatial distribution indicates human interaction through food sharing, thus exploring the cognitive and evolutionary framework and elaborating site function (Enloe 2010; Gabucio and Fernández-Laso 2018). Furthermore, differences in the patterns of carcass transport and social consumption between nearby locations with a similar chronology can be used to discuss the various roles of different sites within a regional subsistence system and consequently infer demography, which has been suggested for the Paris Basin. In the Paris Basin, the nature of the residential camp at Pincevent was determined by the highly social relationships between the different huts, and these relationships were identified through bone refits demonstrating systematic food sharing between different domestic units. These data, corroborated by technological evidence and including the identification of inexpert flintknappers and children (Ploux 1989), suggest the presence of all members of society at the site. In contrast, the frequentation of the Verberie site may attest to the presence of a specific segment of such a society, most probably specialised hunters who occupied this location for short periods during the processing of the carcasses of hunted animals. These food supplies were then further transported to longer term residential campsites, as was the case at Pincevent (Enloe 2004). When dealing with lithics and social behaviours from a spatial perspective, Raw Material Unit analysis (RMU; Roebroeks 1988) can be a valid method when refits have not been systematically applied or are scarce (e.g. Spagnolo et al. 2016; Uthmeier 2006; Vallverdú et al. 2010). In addition, RMU analysis can also be extremely useful when associated with refits (e.g. Machado et al. 2013; Romagnoli and Vaquero 2016; Vaquero et al. 2012).

\section{The challenges and problems for refits in the twenty-first century: limits and perspectives}

Despite the long tradition of refitting studies and the highly informative potential of this method, when integrated into a multidisciplinary research design, the application of refits is still irregular and can be controversial based on the specificity of archaeological science today. There are two main aspects that still limit the use of refits: one is epistemological and the other is related to methodological issues. These two aspects are strictly related.

From an epistemological point of view, some authors have criticised the analysis of archaeological context at such a microscale. Gamble (1991:17) suggested that our main effort as archaeologists must be to understand the 'composite behaviour', going beyond individual events. We agree that our effort must be focused on the reconstruction of behavioural trends and processes in a global scenario and over a long period of time as these are the specific characteristics of archaeology. As much as we see the risk in the exacerbation of single-event analysis, we agree with other authors who have highlighted how the archaeological record is composed of a series of microscale activities (Cahen and Keeley 1980). Moreover, the studies based on an 'assemblage-as-a-whole' perspective can bring a narrow and simplified image of behavioural variability, especially concerning issues such as the manner in which faunal and lithic resources were transported to sites. The 'complete reduction sequence fallacy' is a good example of how inferences made from the sum of different events may change significantly when those events are considered individually. This obliges a look at single events to understand a general scenario. However, it is true that we are still far from the reconstruction of the 'composite behaviour', despite the huge amount of data processed over the last 30 years of refitting studies. Which bring us to the methodological issues. The lack of a systematic application for refitting analysis and of standardisation in the presentation of refit datasets in many cases - which are discussed below-is part of the problem in the patchy scenario that we are dealing with. These limitations have prevented comparisons between sites and making common use of data in new multidisciplinary studies. In fact, it is impossible to go beyond a series of isolated case studies to reach a global understanding of the technological, economic, and social dynamics in Palaeolithic hunter-gatherer communities. There are two main problems concerning the methodological issues. 
The first is the rate of refits. How much can be refit? How much should be refit? These questions are related to three constraints: (1) the time needed to pursue a systematic refitting programme, (2) inter-analyst variability, and (3) a low rate of refits. It should be stressed that a low refitting rate or even the absence of refits is not a fiasco but actual evidence that we must try to explain. Low refit rates may be due to damage or alterations in artefacts (e.g. patina or thermal alterations) or because of a low diversity in the macroscopic aspects of the exploited rocks (e.g. a lack of diversity in colour or an absence of geodes and laminations that can guide the finding of the jointed pieces of a 3D puzzle). However, the absence of refits can also tell us something about the formation dynamics and indicate, for example, that most of the lithic assemblage was produced outside and introduced into the site as a single artefact ('orphans'). There is another cause of a low refit rate: the low resolution of highly developed palimpsests in which the archaeological assemblage is the result of a large number of depositional events, which is often associated with a long period of human frequentation compressed into an archaeological layer. These are, unfortunately, the majority of archaeological deposits in caves and rock shelters, and were also the most commonly used sites in the ancient Palaeolithic era. Effective methods for the dissection of such developed palimpsests are still lacking. A possibility for the improvement of this path is to invest in computers and technology for fieldwork techniques (Martínez-Moreno et al. 2016) and in geostatistics and point pattern modelling for developing probabilistic interpretations and references for quantitative spatial distributions. These novel tools have been applied in regional works (Bevan and Wilson 2013; Crema et al. 2010). Preliminary intra-site studies have shown their potential in site formation studies (Romagnoli and Vaquero 2016), but their implementation must still be explored more deeply. Analyst experience can also contribute to variations in refit rates. Despite the long tradition of refitting studies, experimental tests to check for the variables affecting personal success in finding refits and the parameters needed to assume a rate that is representative of the reality attested by the archaeological record must still be explored in detail. The further development of experimental trials will most likely improve refit procedures and raise the success rate.

The time consumption for refitting is usually regarded as its worst trait because it affects the productivity of a scientific environment, where quick results are expected and researchers hope for stunning results to achieve a better publication ranking, all while dealing with less and less funding and more and more competition. To reduce the time cost of refit search and analysis, the some ongoing studies are developing 3D applications. In regard to refit searching, 3D digital models of each archaeological record and processing through a novel set of algorithms may result in the automation of the refitting process. At present, a few pilot projects have been developed using the Geographic Information System environment (Cooper and Qiu 2006) and working with algorithms for stochastic analysis and the topographic modelling of surfaces to identify similarities between portions of the surfaces of bones, lithics, and ceramics (Schurmans et al. 2002). Nowadays, the interaction between computer science, engineering, and information technology is opening up new intriguing perspectives. However, this realm must be thoroughly researched for the required topology, $3 \mathrm{G}$ geometry, and surface rendering. Partially automated refitting is not yet a reality. Instead, for an analysis of refits, 3D scanning and digital processing can be a useful method for describing the reduction sequences of refitted cores and for approaching refits from a quantitative perspective when considering the measurements, angles, and degrees of convexity of flake surfaces (Delpiano et al. 2017). Furthermore, 3D visual technology can provide a useful tool for dissemination and data sharing and prevent artefacts from prolonged handling.

The second problem still limiting the systematic use of refits for prehistoric studies is the uneven way in which refits have been described. Despite the huge amount of data that has been processed over the last 30 years, available datasets are so diverse and, in many cases, published with such patchy information that they are not useful for comparisons between sites. Comparisons are the first step for building a frame of reference for jumping from single case studies to general behaviours and trends, both in a specific chrono-cultural context and along a diachronic time interval. Comparisons can also provide for the simplification of the search for refits between different sites, integrating data from one archaeological layer within the regional dynamics of human mobility strategies and settlement patterns. It is clear that refits can be useful for different archaeological queries, as shown in this paper. Depending on the topic being investigated with refits, specific data are being analysed, which are not necessarily adequate and useful for all approaches. However, a collective reflection and discussion on improving the standardisation of refit descriptions may lead the further development of this respect and may also affect the enhancement of protocol analysis and a reduction in time costs. Furthermore, a collective discussion on this topic may facilitate the creation of an openaccess repository that could simplify further multidisciplinary and international collaborations, inspire new questions and ideas, and assist in the development of new perspectives for refitting studies. All of this will most likely lead to a novel understanding of past lifeways in palaeoethnography and a better understanding of Palaeolithic adaptations and cultural diversity. 


\section{The big puzzle $\mathbf{3 0}$ years later: a shared, multidisciplinary, Palaeolithic perspective}

In this volume, the current works-in-progress in behavioural studies investigating new and old paths in refitting analysis have been collected. Some of the studies have been mainly focused on site formation processes, looking at the natural and anthropic agents responsible for the spatial distribution of stone tool remains in different depositional contexts. Baena Preysler and Torres Navas tested refits to identify depositional and post-depositional processes in the context of an open-air quarry in the Madrid region during the Lower and Middle Palaeolithic. The analysis of taphonomic processes is also the focus of a study of a sample of lithic tools from the Gran Dolina TD-10 Level in the karstic system of Sierra de Atapuerca in the northern Iberian Peninsula presented by López-Ortega and colleagues. De la Torre and colleagues tested the utility of refits in addressing post-depositional disturbances with an experimental approach through the experimental knapping of four quartzite cores.

Other contributions show the potential of refits for a better understanding of the technological variability in different Palaeolithic periods. Neruda and Nerudová studied refits of Szeletian leaf-points from Moravský Krumlov IV in the Czech Republic. Their analysis demonstrated a specific sequence in the configuration of these tools, suggesting a characteristic procedure in the Early Szeletian in the Moravia region. Delpiano and colleagues used virtual 3D methods to reconstruct the reduction sequences of two multiple refits, attesting to two different volumetric conceptions. They compared the knapping concepts and productivity of a discoidal sequence from the Fumane Cave and a laminar volumetric reduction sequence from the Gravettian occupation at the Piovesello open-air site in northern Italy. Refits of laminar knapping sequences were also analysed by MartínezMoreno and colleagues at Cova Gran in the north-eastern Iberian Peninsula. The authors were able to show the interbedded production of blades, bladelets, and flakes and discuss the technical traits during the transition from the Middle to Upper Palaeolithic. Taller and colleagues presented a technological analysis of lithic sequences in Swabian Gravettian mainly based on the Hohle Fels site. The results are discussed in the frame of human mobility and land-use patterns in the Ach Valley where inter-site refits have been identified.

Several studies were focused on the intra-site analysis of refits, based on the study of high-resolution depositional contexts. Through technical and spatial studies, Machado and colleagues discussed Neanderthal occupational patterns in Stratigraphic Unit IV of the El Pastor rock-shelter. Vaquero and colleagues studied the anthropogenic movements of lithic artefacts at the Abric Romaní Middle Palaeolithic site and discussed long-distance refits in the context of refuse disposal, the functional and social relationships between activity areas, and recycling. Again on the Abric Romaní site, Rosell and colleagues analysed faunal refits looking at the occupational models along the stratigraphy to discuss the variability of Neanderthal occupational patterns at the site during Marine Isotope stage 3. The paper by Karlin and Julien may be considered as a direct link between the 1987 Big Puzzle symposium and our 2017 workshop. They used chert refits from Pincevent to identify individuals according to their skill level in knapping, evaluate the size of the group inhabiting the site, and identify, including through faunal refits, the relationships of social dependency between the Magdalenian families who lived in the different habitations.

The task is certainly not complete if we wish to create a single volume covering all of the most recent refitting studies, and we regret the lack of eminent colleagues who have contributed to the improvement of refitting analysis in Palaeolithic study. However, the case studies that are presented here and the discussions that these data have generated are of great relevance to the planning of the next 30 years of refitting studies. Due to the high-quality data that these studies have provided, refitting should be made a mandatory practice in current archaeological research. Nevertheless, we recognize that there are other considerations that play against refitters. In spite of the latest methodological advances, refitting continues to be a time-consuming activity. The image of the refitter as one who spends hours and hours looking at lithics or bones, sometimes to find only a few refits, may seem discouraging, particularly to the most fervent adherents to human behavioural ecology and an emphasis on net return rate. This issue may be especially important when recruiting new refitters among young students, who feel compelled to publish more and more papers in order to stay alive in the scientific world-you know, publish or perish. Even if we are condemned to be a community of outsiders, we are confident that refitting brings a type of data that no other approach can provide. In fact, refitting represents a certain way of doing science in which the quality and resolution of the data is privileged over the publication rate. It is also as an example of a slow science in that refitting can open new avenues of research into the future.

\section{References}

Arts N, Cziesla E (1990) Bibliography on the subject of refitting stone artefacts. In: Cziesla E, Eickhoff S, Arts N, Winter D (eds) The Big Puzzle: international symposium on refitting stone artefacts, Studies in Modern Archaeology 1. Holos, Bonn, pp 652-683

Audouze F, Enloe JG (1997) High resolution archaeology at Verberie: limits and interpretations. World Archaeol 29:195-207

Bachellerie F, Bordes J-G, Morala A, Pelegrin J (2007) Étude typotechnologique et spatiale de remontages lithiques de Canaule II, site châtelperronien de plein-air en Bergeracois (Creysse, Dordogne). Paleo 19:259-280 
Baena Preysler J, Torres Navas C, Sharon G (2018) Life history of a large flake biface. Quat Sci Rev 190:123-136

Bailey G (2007) Time perspectives, palimpsests and the archaeology of time. J Anthropol Archaeol 26:198-223

Bargalló A, Gabucio MJ, Rivals F (2016) Puzzling out a palimpsest: testing an interdisciplinary study in level O of Abric Romaní. Quat Int 417:51-65

Bargalló A, Mosquera M, Lozano S (2017) In pursuit of our ancestors' hand laterality. J Hum Evol 111:18-32

Bernard-Guelle S, Taylor A, Rué M, Fernandes P, Ajas A, Coudenneau A, Hernandez M, Mercier N (2017) Le site stratifié du Bois Clair à Montguyon (Charente-Maritime, France): récurrences paléolithiques, brièveté des occupations et aires de débitage spécialisées. Paleo 28:31-69

Bevan A, Wilson A (2013) Models of settlement hierarchy based on partial evidence. J Archaeol Sci 40:2415-2427

Binford LR (1978a) Dimensional analysis of behavior and site structure: learning from an Eskimo hunting stand. Am Antiq 43:330-361

Binford LR (1978b) Nunamiut Ethnoarchaeology. Academic, New York

Bodu P, Karlin C, Ploux S (1990) Who's who? The Magdalenian flintknappers of Pincevent (France). In: Cziesla E, Eickhoff S, Arts N, Winter D (eds) The Big Puzzle: international symposium on refitting stone artefacts, Studies in Modern Archaeology 1. Holos, Bonn, pp 143-163

Bosinski G (1975) Die Rekonstruktion des Gönnersdorfer hauses: kommentar zum model. Monographien des RGZM 1:255-273

Brenet M, Guégan S, Claud E, Mesa M, Pasquet V (2018) The Late Solutrean open-air site of Landry (Aquitaine, France). A preliminary spatio-temporal analysis. Quat Int 498:30-50

Cahen D (1976) Nouvelles fouilles a la pointe de la Gombe (ex-pointe de Kalina), Kinshasa, Zaire. L'Anthropologie 80:573-602

Cahen D, Keeley L (1980) Not less than two, not more than three. World Archaeol 12:166-180

Cahen D, Keeley L, van Noten F (1979) Stone tools, toolkits, and human behaviour in prehistory. Curr Anthropol 20:661-683

Castañeda N (2018) Apprenticeship in Early Neolithic societies. The transmission of technological knowledge at the flint mine of Casa Montero (Madrid, Spain), ca. 5300-5200 cal BP. Curr Anthropol 59: 716-740

Chacón MG, Bargalló A, Gabucio MJ, Rivals F, Vaquero M (2015) Neanderthal behaviours from a spatio-temporal perspective: an interdisciplinary approach to interpret archaeological assemblages. In: Conard N, Delagnes A (eds) Settlement dynamics of the Middle Paleolithic and Middle Stone Age, vol IV. Kerns Verlag, Tübingen, pp 253-294

Clark AE (2019) Using spatial context to identify lithic selection behaviors. J Archaeol Sci Rep 24:1014-1022

Close AE (2000) Reconstructing movement in prehistory. J Archaeol Method Theory 7:47-77

Cooper JR, Qiu F (2006) Expediting and standardizing stone artifact refitting using a computerized suitability model. J Archaeol Sci 33: 987-998

Crema ER, Bevan A, Lake MW (2010) A probabilistic framework for assessing spatiotemporal point patterns in the archaeological record. J Archaeol Sci 37:1118-1130

Cziesla E (1990) On refitting of stone artefacts. In: Cziesla E, Eickhoff S, Arts N, Winter D (eds) The Big Puzzle: international symposium on refitting stone artefacts, Studies in Modern Archaeology 1. Holos, Bonn, pp 9-44

Cziesla E, Eickhoff S, Arts N, Winter D (eds) (1990) The Big Puzzle: international symposium on refitting stone artefacts. Studies in Modern Archaeology 1. Holos, Bonn

Delagnes A, Lenoble A, Harmand S, Brugal JP, Prat S, Tiercelin JJ, Roche H (2006a) Interpreting pachyderm single carcass sites in the African Lower and Early Middle Pleistocene record: a multidisciplinary approach to the site of Nadung'a 4 (Kenya). J Anthropol Archaeol 25:448-465

Delagnes A, Féblot-Augustins J, Meignen L, Park S-J (2006b) L'exploitation des silex au Paléolithicuqe moyen dans le Bassin de la Charente: qu'est-ce qui circule, comment...et pourquoi? Bulletin de liaison et d'information, Association des archéologues. Direction des antiquités Poitou-Charentes 35:15-24

Delpiano D, Peresani M, Pastoors A (2017) The contribution of 3D visual technology to the study of Palaeolithic knapped stones based on refitting. DAACH 4:28-38

Deschamps M, Zilhão J (2018) Assessing site formation and assemblage integrity through stone tool refitting at Gruta da Oliveira (Almonda karst system, Torres Novas, Portugal): a Middle Paleolithic case study. PLoS One 13:e0192423. https://doi.org/10.1371/journal. pone. 0192423

Enloe JG (2004) Hunter-gatherer food sharing: social and economic interactions. In: Crothers GM (ed) Hunters and gatherers in theory and archaeology, Center for Archaeological Investigations, Occasional Paper 31. Southern Illinois University, Carbondale, pp 211-240

Enloe JG (2010) Refitting bones: negative evidence, site structure and social organisation. Lithic Technol 35:63-71

Eriksen BV (2009) Review: fitting rocks: lithic refitting examined. PaleoAnthropology 2009:139-141

Foulds FWF (2010) Investigating the individual? An experimental approach through lithic refitting. Lithics 31:6-19

Frison GC (1974) The Casper site: a Hell's Gap bison kill on the high plains. University of Wyoming Press, Laramie

Gabucio J, Fernández-Laso MC (2018) Turning a rock shelter into a home. Neanderthal use of space in Abric Romaní levels M and O. Hist Biol 30:743-766

Gabucio MJ, Cáceres I, Ródriguez-Hidalgo A, Rosell J, Saladié P (2014) A wildcat (Felis silvestris) butchered by Neanderthals in Level $\mathrm{O}$ of the Abric Romaní site (Capellades, Barcelona, Spain). Quat Int 326327:307-318

Gabucio J, Cáceres I, Rivals F, Bargalló A, Rosell J, Saladié P, Vallverdú J, Vaquero M, Carbonell E (2018) Unraveling a Neanderthal palimpsest from a zooarchaeological and taphonomic perspective. Archaeol Anthrop Sci 10:197-222

Gamble CS (1991) An introduction to the living spaces of mobile people. In: Gamble CS, Boismier WA (eds) Ethnoarchaeological approaches to mobile campsites, International Monographs in Prehistory, Ethnoarchaeological series 1, Ann Arbor, pp 1-23

Gaudzinski-Windheuser S (2015) The public and private use of space in Magdalenian societies: evidence from Oelknitz 3, LOP (Thuringia, Germany). J Anthropol Archaeol 40:361-375

Gaudzinski-Windheuser S, Jöris O, Sensburg M, Street M, Turner E (eds) (2011) Site-internal spatial organization of hunter-gatherer societies: case studies from the European Palaeolithic and Mesolithic. Verlag des Römisch-Germanischen Zentralmuseums, Mainz

Hofman JL (1986) Vertical movement of artifacts in alluvial and stratified deposits. Curr Anthropol 27:163-171

Hofman JL, Enloe LG (1992) Piecing together the past: applications of refitting studies in archaeology. BAR International Series 578, Oxford

Jöris O, Street M, Turner E (2011) Spatial analysis at the Magdalenian site of Gönnersdorf (central Rhineland, Germany). In: GaudzinskiWindheuser S, Jöris O, Sensburg M, Street M, Turner E (eds) Siteinternal spatial organization of hunter-gatherer societies: case studies from the European Palaeolithic and Mesolithic. Verlag des RömischGermanischen Zentralmuseums, Mainz, pp 53-80

Julien M, Karlin C (eds) (2014) Un automne à Pincevent. Le campement magdalénien du niveau IV20. Mémoire, vol 57. Société préhistorique française, Paris

Larson ML, Ingbar EE (1992) Perspectives on refitting: critique and a complementary approach. In: Hofman JL, Enloe JG (eds) Piecing 
together the past: applications of refitting studies in archaeology, BAR International Series 578, Oxford, pp 151-162

Leroi-Gourhan A, Brézillon M (1966) L'habitation magdalénien n. 1 de Pincevent près Montereau (Seine-et-Marne). Gallia Préhistoire 9: 263-385

Leroi-Gourhan A, Brézillon M (1972) Fouilles de Pincevent: essai d'analyse ethnographique d'un habitat magdalénien. In: VIIe supplément Gallia Préhistoire. Centre National de la Recherche Scientifique, Paris

López-Ortega E, Bargalló A, de Lombrera-Hermida A, Mosquera M, Ollé A, Rodríguez-Álvarez XP (2017) Quartz and quartzite refits at Gran Dolina (Sierra de Atapuerca, Burgos): connecting lithic artefacts in the Middle Pleistocene unit of TD10.1. Quat Int 433: $85-102$

Machado J, Hernández CM, Mallol C, Galván B (2013) Lithic production, site formation and Middle Palaeolithic palimpsest analysis: in search of human occupation episodes at Abric del Pastor stratigraphic Unit IV (Alicante, Spain). J Archaeol Sci 40:2254-2273

Machado J, Molina FJ, Hernández CM, Tarriño A, Galván B (2017) Using lithic assemblage formation to approach Middle Palaeolithic settlement dynamics: El Salt stratigraphic unit X (Alicante, Spain). Archaeol Anthropol Sci 9:1715-1743

Martínez-Moreno J, Mora Torcal R, Roy Sunyer M, Benito-Calvo A (2016) From site formation processes to human behaviour: towards a constructive approach to depict palimpsests in Roca dels Bous. Quat Int 417:82-93

McCall GS (2010) Refitting rate as a tool for investigating geological and behavioural aspects of site formation: theoretical and methodological considerations. Lithic Technol 35:25-35

McCall GS (2014) Before modern humans: new perspectives on the African Stone Age. Routledge

Modolo M, Rosell J (2017) Reconstructing occupational models: bone refits in Level I of Abric Romaní. Quant Int 435:180-194

Morin E, Tsanova T, Sirakov N, Rendu W, Mallye J-B, Lévêque F (2005) Bone refits in stratified deposits: testing the chronological grain at Saint-Césaire. J Archaeol Sci 32:1083-1098

Morrow TM (1996) Lithic refitting and archaeological site formation processes. A case study from the Twin Ditch Site, Greene County, Illinois. In: Odell GH (ed) Stone tools: theoretical insights into human Prehistory, Interdisciplinary Contributions to Archaeology. Springer, Berlin, pp 345-373

O'Brien M (2015) Evaluating the contemporaneity of households at the Eden-Farson site. Int J Osteoarchaeol 25:653-664

Odell G (1981) The morphological express at function junction: searching for meaning in lithic tool types. J Anthropol Res 37: 319-342

Ortiz Nieto-Márquez I, Baena Preysler J (2017) Did stones speak about people? Flint catchment and Neanderthal behaviour from Area 3 (Cañaveral, Madrid-Spain). Quat Int 435:144-163

Ploux S (1989) Approche archéologique de la variabilité des comportements techniques individuels: l'exeple de quelques tailleurs Magdaléniens à Pincevent. Dissertation, Université Paris X-Nanterre

Rapson DJ, Todd LC (1992) Conjoins, contemporaneity, and site structure: distributional analyses of the Burgas-Holding Site. In: Hofman JL, Enloe JG (eds) Piecing together the past: applications of refitting studies in archaeology. BAR International Series, vol 578. Archaeopress, Oxford, pp 238-263

Roebroeks W (1988) From find scatters to early hominid behaviour: a study of Middle Palaeolithic riverside settlements at MaastrichtBelvédère (The Netherlands). Analecta Praehistorica Leidensia 21, University of Leiden, Leiden

Romagnoli F, Vaquero M (2016) Quantitative stone tools intra-site point and orientation patterns of a Middle Palaeolithic living floor: a GIS multi-scalar spatial and temporal approach. Quartär 63:47-60
Romagnoli F, Vaquero M (2018) The Big Puzzle 30 years after: a shared, multidisciplinary, Palaeolithic perspective - International Workshop, Tarragona (Spain), May 9-11, 2017. Anthropologie LVI/1, pp 63-66

Romagnoli F, Bargalló B, Chacón MG, Gómez de Soler B, Vaquero M (2016) Testing a hypothesis about the importance of the quality of raw material on technological changes at Abric Romaní (Capellades, Spain): some considerations using a high-resolution techno-economic perspective. J Lithic Stud 3. https://doi.org/10.2218/jls.v3i2.1443

Romagnoli F, Nishiaki Y, Rivals F, Vaquero M (2018a) Time uncertainty, site formation processes, and human behaviours: new insights on old issues in High-Resolution Archaeology. Quat Int 474:99-102

Romagnoli F, Gómez de Soler B, Bargalló A, Chacón MG, Vaquero M (2018b) Here and now or a previously planned strategy? Rethinking the concept of ramification for micro-production in expedient contexts: implications for Neanderthal socio-economic behaviour. Quat Int 474:168-181

Rosell J, Blasco R, Fernández-Laso MC, Vaquero M, Carbonell E (2012) Connecting areas: faunal refits as a diagnostic element to identify synchronicity in the Abric Romaní archaeological assemblages. Quat Int 225:56-67

Schiffer MB (1976) Behavioural archaeology. Academic, New York

Schurmans U (2007) Refitting in the Old and New Worlds. In: Schurmans U, De Bie M (eds) Fitting rocks. Lithic refitting examined. Bar International Series 1596, Oxford, pp 7-23

Schurmans U, De Bie M (2007) Fitting rocks. Lithic refitting examined. Bar International Series 1596, Oxford

Schurmans U, Razdan A, Simon A, Marzke M, McCartney P, Van Alfen D, Jones G, Zhu M, Liu D, Bae M, Rowe J, Farin G, Collins D (2002) Advances in geometric modeling and feature extraction on pots, rocks and bones for representation and query via Internet. In: Burenhult G, Arvidsson J (eds) Archaeological Informatics: pushing the envelope, CAA 2001 Proceedings, BAR International Series 1016, Oxford, pp 191-204

Sisk ML, Shea JJ (2008) Intrasite spatial variation of the Omo Kibish Middle Stone Age assemblages: artifact refitting and distribution patterns. J Hum Evol 55:486-500

Smith WC (1894) Man the primeval savage. London, Stafford

Smith ME, Feinman GM, Drennan RD, Earle T, Morris I (2012) Archaeology as a social science. Proc Natl Acad Sci 109:7617-7621

Spagnolo V, Marciani G, Aureli D, Berna F, Boscato P, Ranaldo F, Ronchitelli A (2016) Between hearths and volcanic ash: the SU 13 palimpsest of the Oscurusciuto rock shelter (Ginosa-Southern Italy): analytical and interpretative questions. Quat Int 28:105-121

Spurrell FCJ (1880) On implements and chips from the floor of a Palaeolithic workshop. Archaeol J 37:249

Street M, Gelhausen F, Grimm S, Moseler F, Niven L, Sensburg M, Turner E, Wenzel S, Jöris O (2006) L'occupation du bassin de Neuwied (Rhénanie centrale, Allemagne) par les Magdaléniens et les groupes à Federmesser (aziliens). Bull Soc Prehist Fr 103:753780

Turq A, Roebroeks W, Bourguignon L, Faivre JP (2013) The fragmented character of Middle Palaeolithic stone tool technology. J Hum Evol 65:641-655

Uthmeier T (2006) Stone tools, horses and cognition: transformation of lithic raw materials at the Middle Paleolithic open air kill and butchery site of Kabazi II, Level III/1. In: Chabai V, Richter J, Uthmeier T (eds) Kabazi II: the 70000 years since the last interglacial. Simferopol, Cologne, pp 253-269

Vallverdú J, Vaquero M, Cáceres I, Allué E, Rosell J, Saladié P, Chacón MG, Ollé A, Canals A, Sala R, Courty MA, Carbonell E (2010) Sleeping activity area within the site structure of archaic human groups. Curr Anthropol 51:137-145

van Noten F (1971) Excavations at Munyama cave. Antiquity 45:56-58 
Vaquero M (2008) The history of stones: behavioural inferences and temporal resolution of an archaeological assemblage from the Middle Palaeolithic. J Archaeol Sci 35:3178-3185

Vaquero M (2011) New perspectives on recycling of lithic sources using refitting and spatial data. Quartär 58:113-130

Vaquero M, Romagnoli F (2018) Searching for lazy people: the significance of expedient behavior in the interpretation of Paleolithic assemblages. J Archaeol Method Theory 25:334-367

Vaquero M, Chacón MG, García-Antón MD, Gómez de Soler B, Martínez K, Cuartero F (2012) Time and space in the formation of lithic assemblages: the example of Abric Romaní Level J. Quat Int 247:162-181
Vaquero M, Bargalló A, Chacón MG, Romagnoli F, Sañudo P (2015) Lithic recycling in a Middle Paleolithic expedient context: evidence from the Abric Romaní (Capellades, Spain). Quant Int 361:212-228

Vaquero M, Fernández-Laso MC, Chacón MG, Romagnoli F, Rosell J, Sañudo P (2017) Moving things: comparing lithic and bone refits from a Middle Paleolithic site. J Anthropol Archaeol 48:262-280

Villa P (1982) Conjoinable pieces and site formation processes. Am Antiq 47:276-290

Publisher's note Springer Nature remains neutral with regard to jurisdictional claims in published maps and institutional affiliations. 